\title{
First quarter sees 27 firms raise \$649.7 million
}

Though it got off to a fast start, the first quarter saw public financing take another tumble, as the sector's valuation dropped 33 percent.

TABLE 1. Biotech's 1993 first-quarter offerings.
NEW YORK--Last year public financing of U.S. biotech companies soared from peaks to valleys. Yet the year-which saw 75 companies raise $\$ 2$ billion and which followed 1991 's record of 85 companies taking in $\$ 3.7$ billion-_ended on a high note, with fully 36 companies waiting to conduct stock offerings.

But this year's first quarterthough it got off to a fast start-saw public financing take another tumble. Indeed, in late February, when Synergen (Boulder, CO) reported disappointing results from phase III clinical trials of its highprofile sepsis product, public financing bottomed out, as the biotech sector lost an immediate 10 percent of its market value. Overall, the sector's valuation dropped 33 percent during the quarter. Amgen's (Thousand Oaks, CA) disappointing first-quarter sales and earnings also contributed to the sector's fall, as did the growing fear that the Clinton administration will attack not only the high prices of me-too drugs but also the astronomical prices of innovative bioph- armaceuticals. So with the stocks of established companies trading at discounts, investors closed the quarter choosing to invest-or not invest-in them, instead of initial public offerings (IPOs) or even secondary offerings.

In all, the first quarter saw 27 companies raise $\$ 649.7$ million (Table 1). Without a doubt, the quarter's first month was a prosperous one, with eight secondaries taking home $\$ 215$ million and five IPOs bringing in $\$ 180.5$ million. In fact, January saw biotech companies raise more money than they had raised in the preceeding eight months combined. The quarter was particularly generous to IPOs, as at least four companies priced their offerings at the high end of their filing range and offered more shares than they anticipated. These firms included AutoImmune (Lexington, MA), BioSurface Technology (Cambridge, MA), Cell Genesys (Foster City, CA), and Shaman Pharmaceuticals (San Carlos, CA).

Yet even in January, the financing window showed signs of weakness.
At least five of the companies that conducted secondary offerings priced their shares at a lower price, compared to their previous stock offerings, "Even before Synergen hit, the window was cracking, forcing companies to do secondaries on less favorable terms," says Mark Edwards, managing director of $\mathrm{Re}$ combinant Capital (San Francisco, CA).

February, for its part, found six secondaries capturing $\$ 132.2$ million and two IPOs netting $\$ 21.5$ million. Signs of weakness continued, though, with three of the companies floating secondaries pricing their shares lower than in their prior public financings. March's performance-coming in Synergen's wake - was dismal, as four secondaries raised $\$ 82.1$ million and two IPOs took in $\$ 17.4$ million.

As the quarter ended, 25 companies were in process, including 17 IPOs and eight secondaries. "Actually, a lot of these companies have already withdrawn their registrations," says Edwards.

-B.J. Spalding

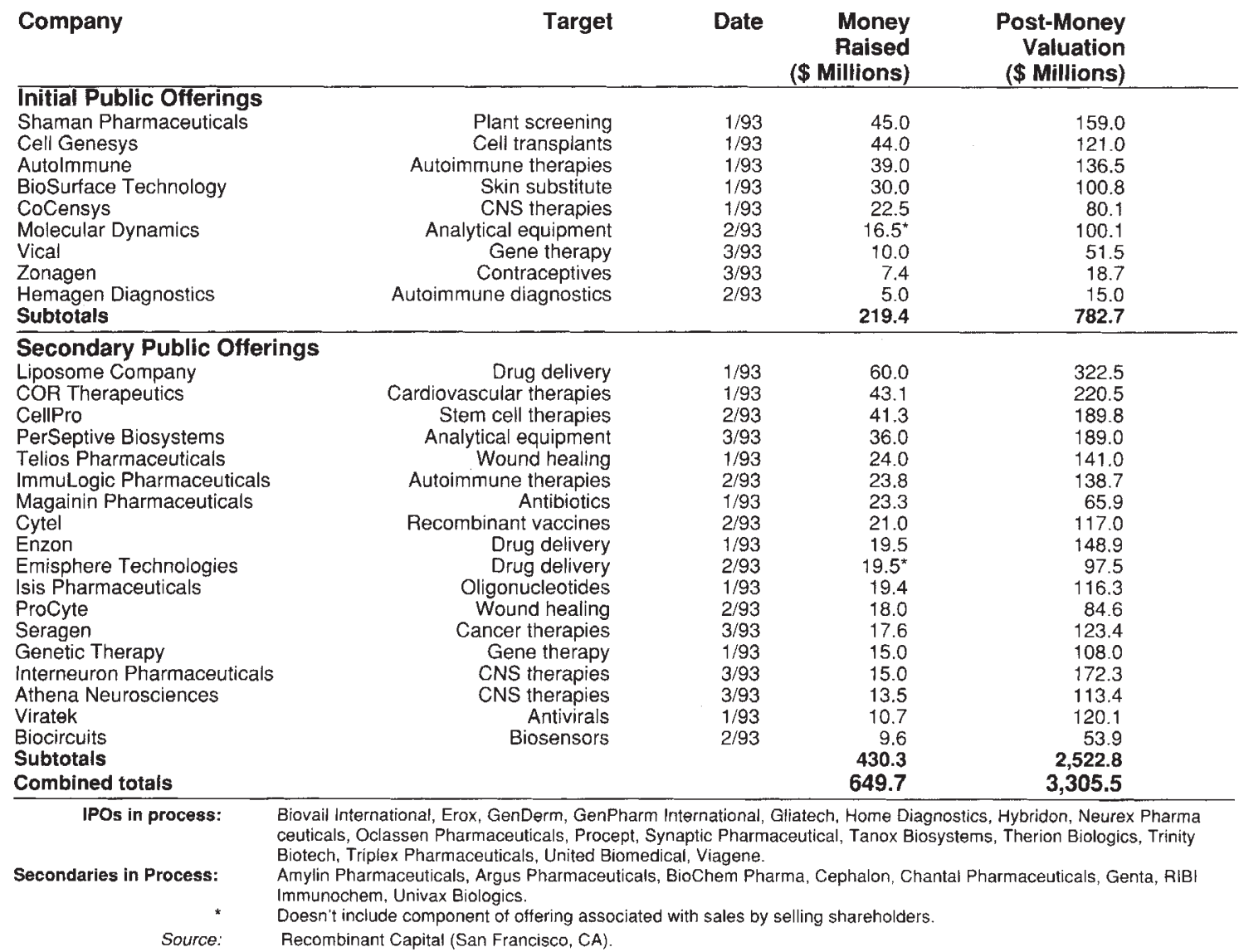

